\title{
Erratum: An iteration normalization and test method for differential expression analysis of RNA-seq data
}

\author{
Yan Zhou ${ }^{1 *}$, Nan Lin ${ }^{2}$ and Baoxue Zhang ${ }^{3}$
}

\author{
* Correspondence: \\ zhouy1016@163.com \\ ${ }^{1}$ Institute for Genomic Biology, \\ University of Illinois at \\ Urbana-Champaign, Champaign, USA \\ Full list of author information is \\ available at the end of the article
}

\section{Erratum}

Following publication of our paper in BioData Mining [1], it came to light that numerous sections of text were similar or identical to a previous publication by Robinson and Oshlack [2]. In extending the method proposed by Robinson and Oshlack, we inadvertently copied text from their article [2]. We acknowledge that these areas of text should have been clearly indicated as quotations or excluded entirely. We sincerely apologize for this oversight.

\footnotetext{
Author details

${ }^{1}$ Institute for Genomic Biology, University of Illinois at Urbana-Champaign, Champaign, USA. ${ }^{2}$ Department of Mathematics, Washington University in Saint Louis, St Louis, USA. ${ }^{3}$ Key Laboratory for Applied Statistics of MOE and School of Mathematics and Statistics, Northeast Normal University, Changchun, P. R. China.

Received: 26 November 2014 Accepted: 26 November 2014

Published online: 12 December 2014

References

1. Zhou Y, Lin N, Zhang B: An iteration normalization and test method for differential expression analysis of RNA-seq data. BioData Min 2014, 7:15.

2. Robinson MD, Oshlack A: A scaling normalization method for differential expression analysis of RNA-seq data. Genome Biol 2010, 11:R25. http://genomebiology.com/content/pdf/gb-2010-11-3-r25.pdf.

doi:10.1186/s13040-014-0030-4

Cite this article as: Zhou et al:: Erratum: An iteration normalization and test method for differential expression analysis of RNA-seq data. BioData Mining 2014 7:30
}

\section{Ciomed Central}

\section{Submit your next manuscript to BioMed Central and take full advantage of:}

- Convenient online submission

- Thorough peer review

- No space constraints or color figure charges

- Immediate publication on acceptance

- Inclusion in PubMed, CAS, Scopus and Google Scholar

- Research which is freely available for redistribution

Submit your manuscript at

C Biomed Central 